\title{
Human trafficking from Ukrainian cities and villages: Current trends
}

\author{
Andriy Babenko ${ }^{1}$, Vladislava Batyrgareieva ${ }^{2}$, and Alina Kalinina ${ }^{2, *}$ \\ ${ }^{1}$ Odessa State University of Internal Affairs, Odessa, Ukraine \\ 2 Àcademician Stashis Scientific Research Institute for the Study of Crime Problems National \\ Academy of Law Sciences of Ukraine, Kharkiv, Ukraine
}

\begin{abstract}
The official statistics of the Prosecutor General's Office of Ukraine has recorded that in 2017 the number of cases of human trafficking from Ukraine increased threefold (342 cases versus 115 in 2016). Such a sharp growth of the aforementioned crime was last observed in 2005 to 2006. Today, there are no administrative and territorial districts in Ukraine from which future victims of human traffickers would not be recruited. According to criminal proceedings, about $70 \%$ of human trafficking victims are residents of large Ukrainian cities. The aim of this research is to investigate current trends of human trafficking phenomenon from Ukrainian cities and villages and to present the ways how the victims fall into slavery. The revealed trends of the human trafficking from Ukraine allow us to affirm that whereas similarity of social and demographic, moral and physiological characteristics of urban and rural residents, the second ones have a higher level of risk to become a victim of human trafficking. The results obtained allow us to develop evidence-based recommendations for the human trafficking from Ukraine decreasing as from the hole country, as rural locals, in particular. The new feature in human trafficking is a negative trend that Ukraine is changing from the country in which human trafficking victims originate into the destination country for human trafficking.
\end{abstract}

Key words: human trafficking, slavery, exploitation, victims, residents of cities and villages.

\section{Introduction}

For over two decades, human trafficking has been recognized as one of the most dangerous types of international criminal business which is a flagrant violation of fundamental human rights and freedoms. According to UN experts, this type of crime ranks third in terms of profitability after drug and weapon trafficking $[1,2]$. The total annual income from human trafficking is from 5 to 9 billion USD [3]. About 2.5 million people from 127 different countries are being exploited in 137 countries of the world due to their involvement in the process of human trafficking [4]. The global financial and economic crisis, which was the result of a decline in the indicators of a number of socio-economic issues around the world [5], only aggravated the human trafficking phenomenon (either for sexual exploitation, or for the purpose of attraction in forced labour). At present, almost all regions of the world are covered with this disaster. This predetermines the urgency of creating an effective system of collective opposition to this extremely negative phenomenon by efforts of the entire civilized world.

\footnotetext{
* Corresponding author: alina.kalinina@ukr.net
}

(C) The Authors, published by EDP Sciences. This is an Open Access article distributed under the terms of the Creative Commons Attribution License 4.0 (http://creativecommons.org/licenses/by/4.0/). 
Fight against human trafficking is certainly part of the system of the collective opposition both from Ukraine and Ukraine itself. After all, the settlements of our country are not an exception to the analysed phenomenon, which is the product of the world wide web of human traffickers: at present, there are no such regions in Ukraine where future victims of human traffickers would not be recruited. This becomes very relevant especially in relation to the situation with the migration of labour resources from Ukraine, which, under the conditions of the extension of crisis development in the Ukrainian economy [6-8], large external debt, property stratification of society and the difference in the quality of social services in Ukrainian cities and towns, rising unemployment (especially in small Ukrainian cities and rural areas) and involuntary part-time employment, a significant gap in wage levels, on the one hand, in Ukraine and in foreign countries, and on the other hand, in Ukrainian cities and rural areas, the military conflict in the east of the country will only deepen. Ukraine is currently recognized as one of the largest donor countries in Europe where external labour migration has become an objective reality $[9$, p. $98 ; 10$, p. 5]. The regulation of population's labour migration both in Ukraine and abroad has become an overcomplicated problem, as these processes are taking increasingly unlawful forms. One of these forms is human trafficking.

The goal of this research is to establish modern trafficking trends in Ukrainian cities and villages and to analyse the geography of its distribution on the basis of a comprehensive study of this phenomenon, as well as to clarify the criminological portrait of persons who have suffered from the crime provided for in Art. 149 of the Criminal Code of Ukraine, and the main reasons that contribute to the existence and further spread of this phenomenon in Ukrainian cities and villages.

\section{Methods}

The methodological basis of the research is, first of all, the official statistical information of the Department of Information and Analytical Support of the Ministry of Internal Affairs of Ukraine; Office of the organizational support of the National Register of Pre-trial Investigations and the Information and Analytical Work of the General Prosecutor's Office of Ukraine; sentences contained on the official website of the State Judicial Administration of Ukraine; information from the State Statistics Service of Ukraine for the period of 2014-2017; and secondly, the information of the United Nations Office on Drugs and Crime; thirdly, in 2017, a survey of ordinary Ukrainian citizens in Kharkiv and Odessa regions regarding the risk assessment to become the victim of human traffickers if these citizens decide to go abroad for earnings; fourthly, a cartographic method that gives a clear idea of ??the level of vulnerability of different regions of Ukraine by the results of the disclosure of cases of human trafficking; fifth, the tabular method, which especially allowed the disclosure of quantitative and qualitative parameters of the phenomenon under consideration.

Empirical data is processed and analysed using descriptive statistics technology, calculations and mapping using Adobe Photoshop CS6, Microsoft Excel 2016, Microsoft Word 2016 and QuickMap 2.2.

\section{Results}

According to the General Prosecutor's Office of Ukraine, until recently, there was certain stabilization in the dynamics of crimes in Ukraine connected with human trafficking. However, in 2017, the number of such cases registered in Ukraine has increased almost three times (Table 1). Such a sharp increase was most recently observed in 2005-2006. The situation has become so critical that Ukraine's Ministry of Internal Affairs announced 2017 as the Year of Combating Trafficking in Persons. The number of detected persons herewith is 
Table 1. Level and dynamics of human trafficking or other illegal human rights (Article 149 of the Criminal Code of Ukraine).

\begin{tabular}{|c|c|c|c|c|c|c|}
\hline \multirow{2}{*}{$\begin{array}{c}\text { Parameters/ } \\
\text { Year }\end{array}$} & \multirow{2}{*}{$\begin{array}{c}\text { Amount of } \\
\text { crime in whole }\end{array}$} & \multirow{2}{*}{$\begin{array}{c}\text { Dynamics of } \\
\text { crimes (\%) }\end{array}$} & \multicolumn{3}{|c|}{$\begin{array}{c}\text { Distribution of crimes by parts } \\
\text { Article 141 of the Criminal Code }\end{array}$} & \multirow{2}{*}{$\begin{array}{c}\text { Amount of } \\
\text { criminals }\end{array}$} \\
\cline { 4 - 6 } & & & p. 1 & p. 2 & p. 3 & \\
\hline 2014 & 118 & - & 14 & 92 & 12 & 77 \\
\hline 2015 & 110 & -7.0 & 16 & 73 & 21 & 79 \\
\hline 2016 & 115 & +4.5 & 19 & 89 & 7 & 59 \\
\hline 2017 & 342 & +297.0 & 24 & 273 & 45 & 132 \\
\hline
\end{tabular}

Table 2. Number of persons who have suffered from the crime, stipulated by art. 149 of the Criminal Code of Ukraine (2014-2017).

\begin{tabular}{|l|c|c|c|c|c|}
\hline $\begin{array}{l}\text { Parameters/ } \\
\text { quantitative } \\
\text { Indexes }\end{array}$ & $\mathbf{2 0 1 4}$ & $\mathbf{2 0 1 5}$ & $\mathbf{2 0 1 6}$ & $\mathbf{2 0 1 7}$ & Total \\
\hline Parts 1-3 P. 149 & 98 & 113 & 86 & 309 & 597 \\
\hline $\begin{array}{l}\text { P. 2 and P. 3 from } \\
\text { Art. 149 }\end{array}$ & $89(90.8 \%)$ & $101(89.4 \%)$ & $74(86.1 \%)$ & $295(95.5 \%)$ & $559(93.6 \%)$ \\
\hline
\end{tabular}

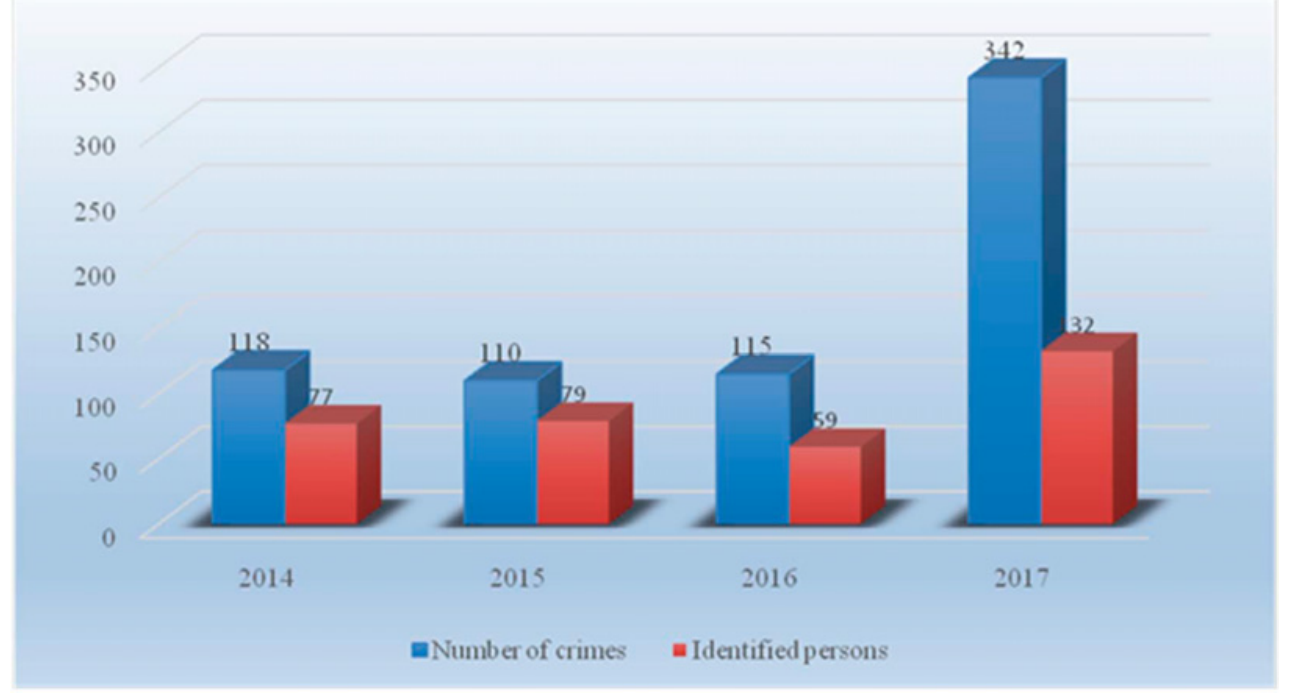

Fig. 1. Correlation of the number of registered crimes provided by Art. 149 of the Criminal Code of Ukraine, and detected criminals.

almost twice less than the number of registered law violations (Fig. 1). However, the number of victims of human trafficking is only increasing (Table 2) [11-14].

As is evident, the vast majority of crimes ( $87.5 \%$ on average), are committed under aggravating or particularly aggravating circumstances in circumstances (Parts 2 and 3 of Article 149 of the Criminal Code). These include cases of human trafficking: 1) under age or a minor; 2) regarding several persons; 3 ) repeatedly committed; 4) by prior conspiracy by a group of persons or an organized group; 5) committed by an official using the official position; 


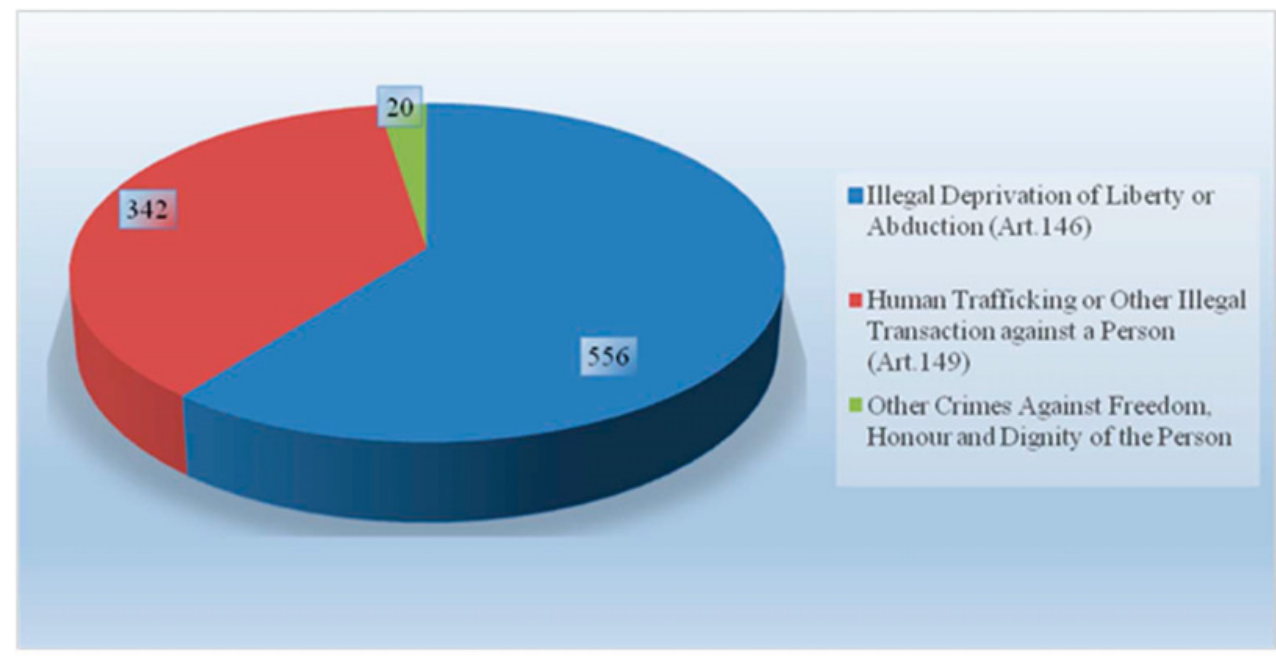

Fig. 2. Crimes Against Freedom, Honour and Dignity of the Person.

Table 3. Number of the existing population of Ukraine at the place of residence (as of January 1, 2017) [16].

\begin{tabular}{|l|l|l|l|l|l|}
\hline $\begin{array}{l}\text { Parameters/ } \\
\text { quantitative } \\
\text { Indexes }\end{array}$ & $\begin{array}{l}\text { Number of } \\
\text { available } \\
\text { population } \\
\text { (persons) }\end{array}$ & \multicolumn{2}{|c|}{ Including (persons) } & \multicolumn{2}{|l|}{ Specific gravity in total (\%) } \\
\cline { 3 - 6 } & & $\begin{array}{l}\text { Urban } \\
\text { population }\end{array}$ & $\begin{array}{l}\text { Rural } \\
\text { population }\end{array}$ & $\begin{array}{l}\text { Urban } \\
\text { population }\end{array}$ & $\begin{array}{l}\text { Rural } \\
\text { population }\end{array}$ \\
\hline Ukraine & $42,584,542$ & $29,482,313$ & $13,102,229$ & 69.23 & 30.77 \\
\hline
\end{tabular}

6) committed by a person from whom the victim was materially or otherwise dependent; 7) is connected with violence, dangerous to the life or health of the victim or his relatives, or with the threat of the use of such violence, including those that caused grave consequences). $93.6 \%$ of victims of trafficking suffer from such actions.

The share of human trafficking among all crimes against the will, honour and dignity of a person envisaged by Section III of the Special Part of the Criminal Code of Ukraine constitutes $37 \%$, taking the second step after cases of unlawful imprisonment or abduction of a person (Fig. 1).

Using the cartographic method [15], it was found that the most vulnerable regions suffering from this crime were the Kyiv, Odesa, Kharkiv and Dnipropetrovsk regions (Map 1).

The conducted criminological research has established that recruitment of about $70 \%$ of victims of human trafficking based on materials examined by the courts of criminal proceedings took place in large Ukrainian cities. Two thirds of such cases herewith fall into such cities as Kyiv, Odessa, Kharkiv and Dnipro.

This indicator proportionally reflects natural distribution of Ukrainian population in cities and rural areas.

At first sight, a similar situation seems to indicate that the inhabitants of the largest cities are more likely to become victims of human trafficking. However, the study of sociodemographic data of the victims of human trafficking showed that only $59.3 \%$ of them are inhabitants of large cities, the rest are inhabitants of settlements and small towns (40.7\%). It 


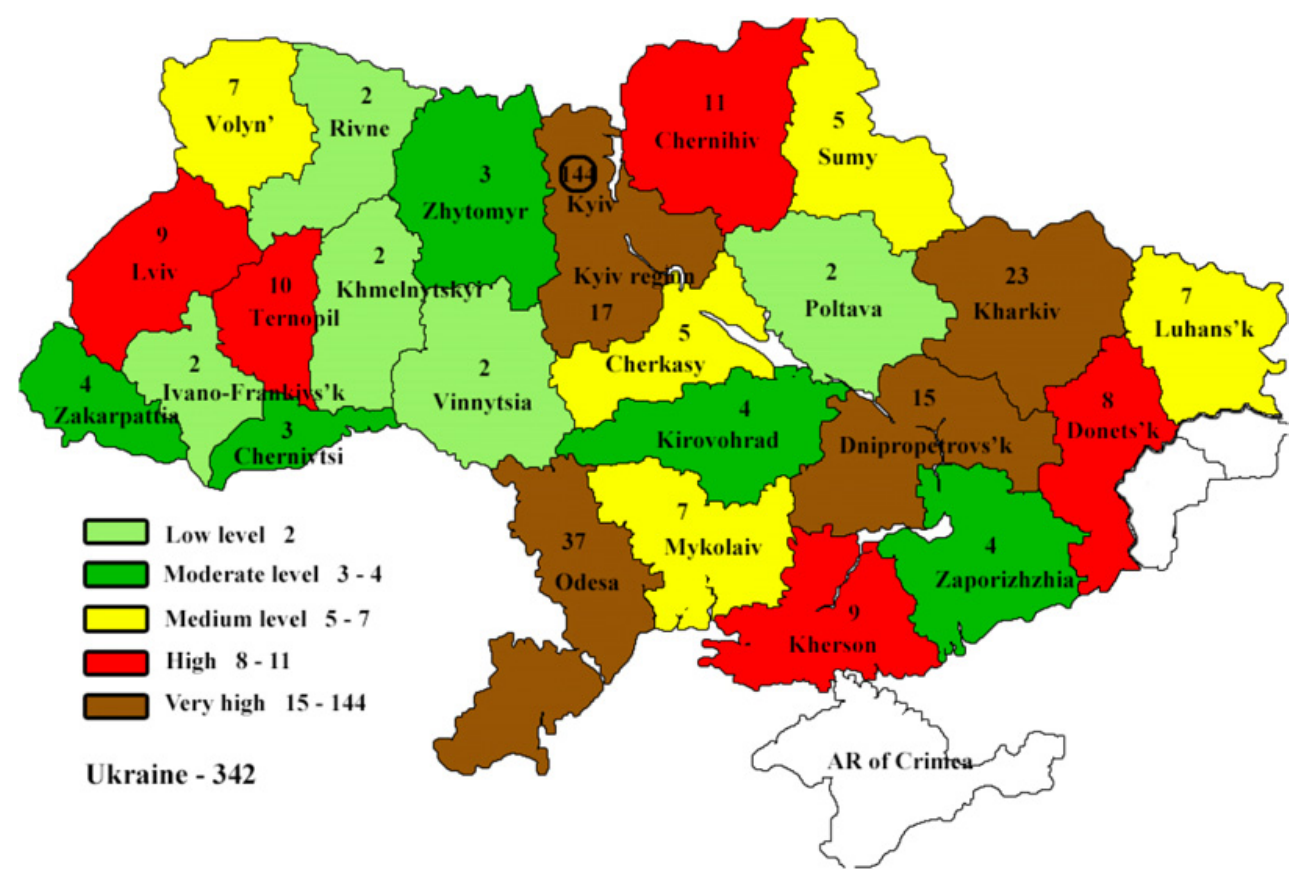

Map 1. Level of human trafficking, recorded in the regions of Ukraine in 2017.

means that the risk of becoming a potential victim from rural residents is significantly higher (1.32) than urban residents $(0.86)^{1}$, that is, approximately by half.

Pursuant thereto, the research task was to provide an explanation for the occurrence of such imbalance of risks. The study of the victims' biographies, as well as the results of the survey of ordinary citizens provided an opportunity to explain the reason for the artificial increase in cases of human trafficking from the largest cities of Ukraine. Before the victims are caught by the traffickers they try to look for work in large cities for some time, thus, becoming the inhabitants of these cities. When rural residents fail to do this or they are not happy with low wages at home, they agree on the offer of criminals to go abroad for work, sometimes deliberately looking for any, including illegal, ways to get to one or another country for earnings. Thus, the following is typical for rural residents: first, internal migration to large and especially large Ukrainian cities searching for work in a native country, further - targeted search of work abroad, and finally - exit abroad and into slavery. It is appropriate to dwell in detail on the problem of the risk of traffickers entering the trafficking network.

The researchers of general population labor migration of the and human trafficking, in particular, study these phenomena from the standpoint of different approaches, concepts, theories, among which the risk theory is assigned the significant role [see 17-26, etc.]. Risks are usually spoken when a decision was made, in case of rejection of which losses could not occur [27, p. 211]. The most dangerous among the most significant risks of labour migration abroad is the risk of being drawn into debt bondage for the unlawful acts of traffickers.

\footnotetext{
${ }^{1}$ Note. These coefficients are a mathematical ratio proportion of urban and rural residents who have been victims of traffickers based on criminal proceedings, and the proportion of urban and rural population in the total number of all residents of Ukraine respectively.
} 
Table 4. Estimates of personal risk of becoming a victim of human trafficking by the inhabitants of Ukraine.

\begin{tabular}{|c|c|c|c|c|c|c|c|}
\hline \multirow[t]{2}{*}{$\begin{array}{l}\text { Parameters/ } \\
\text { quantitative } \\
\text { indicators }\end{array}$} & \multicolumn{3}{|c|}{$\begin{array}{l}\text { Awareness of respondents of the } \\
\text { existence of human trafficking } \\
\text { cases }\end{array}$} & \multicolumn{4}{|c|}{$\begin{array}{l}\text { Probability to get in the } \\
\text { human trafficking situation when } \\
\text { being employed abroad according to } \\
\text { respondents' personal assessment) }\end{array}$} \\
\hline & $\begin{array}{l}\text { heard of } \\
\text { such } \\
\text { cases }\end{array}$ & $\begin{array}{l}\text { never } \\
\text { heard } \\
\text { about } \\
\text { them }\end{array}$ & $\begin{array}{l}\text { hard to } \\
\text { answer }\end{array}$ & high & short & excluded & $\begin{array}{l}\text { hard to } \\
\text { answer }\end{array}$ \\
\hline $\begin{array}{c}\text { Urban } \\
\text { Residents }\end{array}$ & $\begin{array}{c}136 \\
(90.7 \%)\end{array}$ & $\begin{array}{c}5 \\
(3.3 \%)\end{array}$ & $\begin{array}{c}9 \\
(6.0 \%)\end{array}$ & $\begin{array}{c}27 \\
(18.0 \%)\end{array}$ & $\begin{array}{c}52 \\
(34.7 \%)\end{array}$ & $\begin{array}{c}17 \\
(11.3 \%)\end{array}$ & $\begin{array}{c}54 \\
(36.0 \%)\end{array}$ \\
\hline $\begin{array}{c}\text { Rural } \\
\text { residents }\end{array}$ & $\begin{array}{c}105 \\
(70.0 \%)\end{array}$ & $\begin{array}{c}26 \\
(17.3 \%)\end{array}$ & $\begin{array}{c}19 \\
(12.7 \%)\end{array}$ & $\begin{array}{c}13 \\
(8.7 \%)\end{array}$ & $\begin{array}{c}49 \\
(32.7 \%)\end{array}$ & $\begin{array}{c}41 \\
(27 . \%)\end{array}$ & $\begin{array}{c}47 \\
(31.3 \%)\end{array}$ \\
\hline
\end{tabular}

During the research, information was received on the awareness of ordinary citizens at working age - residents of urban and rural areas - regarding the problem of trafficking among human beings and the risk of harm from illegal actions of a trafficker if a decision was made to work abroad.

Thus, a significant part of both urban and rural residents cannot be identified with the risk of becoming victims of traffickers, which is indicative of the still insufficient awareness of citizens about the analysed problem and the criminal schemes of getting a person into slavery. Moreover, rural residents look more assertive that they will not encounter such situations if they decide to look for work abroad: their chances of avoiding troubles are estimated at two and a half times higher than urban dwellers. In this case, it is important to find out whom the risk of falling into slavery may endanger. The research found that recruitment of victims more often was carried out by acquaintances or relatives, etc. $(61.1 \%)$, because the victims trust them most.

Rural and urban residents of Ukraine differ in their preferences in choosing the types of work they would agree to. Thus, urban female residents prefer work related to the service sector (tourism and show business, child care or sick care), while rural residents agree to work on farmland and as housewives. Men regardless of the region of origin prefer agriculture, construction and transport related services. The materials of criminal proceedings, however, show a somewhat different situation. Most victims were indeed invited to work as dancers in night clubs, cabaret, etc. (41.4\%); $24.2 \%$ were offered to provide intimate services; $13.8 \%$ to work as waitresses; in agriculture $-9.9 \%$; caring for a child or patients $-3.4 \%$; to do housework - also $3.4 \%$; the rest $-3.9 \%$. However, the vast majority of victims $(98.2 \%)$ have been sexually exploited in one way or another, even though there are cases of such recognition by men aged 25-35 aged between the ages of 25 and 35, mostly employed in construction and agricultural production. But often researchers did not establish if the kind of "work", which the victims had been doing in Ukraine, was similar to their work abroad (in other words, if they had provided sexual services on a commercial basis). It can be said with a high degree of certainty, that such "work" had been done by $14.3 \%$ of victims, $32.2 \%$ of them had not ever done anything of the kind (this information was established in criminal files) However as for the most part of victims (more than 50\%) we can say most probably, that they had prostituted in Ukraine too.

As for the analysis of the previous work activity of the victims, only $19.2 \%$ of urban and $14.2 \%$ of rural residents worked in Ukraine officially until their departure abroad. The vast majority of victims $(63.3 \%)$ left Ukraine by their choice, with reliable information about the 
actual nature of the work they are supposed to perform, including sexual services. In other cases, travellers did not have reliable information. However, the facts of forced exportation were not stated, although such facts occurred earlier (15-20 years ago) [28, p. 4]. Therefore, nowadays the only source of danger to migrant workers from Ukraine is the mediator, to whom they apply for the purpose of employment and who undertakes the financing of the travel, especially purchasing tickets, visas processing, passports and so on. These financial expenditures of the travel are the additional motivation that does not permit an emigrant to refuse leaving even if some doubts arise as for its save. Herewith $23.8 \%$ of victims implied that abroad they had been subject to physical violence from the guilty persons: they were beaten, belaboured, abandoned without food and water. Also about $54.8 \%$ of victims said that the psychic violence was applied to them (in particular, the threat of physical violence, the threat to tell relatives and friends about what they were doing abroad, other compromising data, etc.). Both physical and psychic violence took place toward $9.7 \%$ of victims. No violence by the perpetrators, according to the victims' testimonies, was used against $11.7 \%$. As we see, violence was used against most victims. Such behaviour with them testifies about coercion and personal restraint. Sometimes victims even had no opportunity to communicate with anyone, because during their time out of duties they were hold in a closed space. In more cases the only chance to get freedom was a police raid, after that they were deported.

The next alarming tendency, which we fixed during the victims' interview, is the fact, that when women after their returning home bring with them some money as a payment for sexual services (even if they were channel into prostitution by a fraud), they do not identify themselves as victims, despite the awful conditions in which they were abroad. Moreover, such women are now themselves trying to take out new women, having the necessary knowledge about how to better adapt to living abroad, how and where to find a "normal" job, getting good money for it, and so on. In addition, they expect that they will now be able to work without mediator, to independently seek housing, the rent for which it is easier to pay with their companions. It is interesting to note that the main reason for exposing traffickers by the victims, which we managed to establish based on the results of the study of materials of criminal proceedings, was often the banal desire of these victims to "punish" the "mediators" for not receiving the promised profit.

The risk group among women suffering from human trafficking, like 15-20 years ago, includes people aged 16-35 years. The victims (77.9\%) have a low educational level, and only $25.0 \%$ have families and children. The victim's behaviour is manifested in their frivolity $(52.2 \%)$, underestimation of the risks associated with working, weakening of social protection of population from the state, military events in the East Ukraine, demand for sexual services and cheap labour abroad, lack of hope for the future, internationalization of the shadow economy, formation of international criminal associations; corruption of government officials involved in the issuance of documents required for travel abroad, etc. Mass and individual psychology of consumerism, covetousness, moral degradation of a large number of potential victims and legal nihilism of the population of Ukraine play a major role in the restoration and existence of this criminal offense, in which $66.7 \%$ of crimes are committed by organized groups. Therefore, the conduct of the trafficking victim has an important determination role in the expansion of this crime. In view of the increased victimization of aggrieved persons of this crime, which in the vast majority of cases is due to the desire for high earnings, immoral way of life, frivolity and naivety of the person, special urgency is required in order to develop measures for prevention of victims of human trafficking, especially among women. 


\section{Discussion}

A further negative trend, which arose a few years ago in Ukraine, needs to be further explored - from the country of origin of victims of trafficking, it is turning into a country of destination of living goods, as more and more citizens of other states become affected by various forms of exploitation in Ukraine: sexual, including those involved in forced prostitution and pornography, labour - in agriculture, construction, service sectors, forced begging and organ extraction $[29$, p. 6]. However, only a small number of foreigners are currently recognized as victims of human trafficking. Instead, such individuals tend to be expelled outside our country.

One more aspect related to this phenomenon is to be studied, namely: were there any new causes that had not been noticed before, among the reasons that led to the existence and reproduction of this phenomenon? We respond negatively to this question so far: no new causes arose except for socio-economic and personal reasons that existed before in the complex of human trafficking 30, p. 32.

Another tendency to be clarified is that, along with human trafficking, the problem of independent labour migration from Ukraine is still partly illegal. Human trafficking herewith cannot be identified as illegal labour migration, since it is a matter of somewhat different problems, although they are closely interconnected.

It is often argued in the media that Ukrainian citizens are supposedly sold for the purpose of their further use in violent conflicts. However, there is another problem - misconception of the notion of "human trafficking" of other unlawful actions against Ukrainian prisoners of war and civilians. These include cases requiring money for the release of these individuals, which is a particular problem that needs to be studied.

\section{Conclusions}

Human trafficking is one of the most difficult problems both in Ukraine and in most regions of the world. Its solution should be based on the combination of collective efforts of all interested countries of the world. Identification of current trends in human trafficking from Ukrainian cities and towns, reflecting regional peculiarities in particular, suggests that although sociodemographic and moral, and psychological characteristics of urban and rural residents are similar, rural residents have a higher risk of becoming victims of human trafficking than urban residents. The obtained results, firstly, allow us to familiarize the general population with the main traits of human trafficking from Ukrainian cities and villages. Secondly, they can be based on the improvement of information and analytical support of the work of state and law enforcement bodies in order to reduce the incidence of human trafficking from Ukraine in general, and from rural areas, in particular.

\section{References}

[1] Combatting Human Trafficking. Available: http://www.austria.org/humantrafficking/

[2] Breaking the Chain: Corruption and Human Trafficking. Available: https://www . transparency.org/news/feature/breaking_the_chain_corruption_and_ human_traffickin

[3] Торгівля людьми. Available: http://www.gpedia.com/uk/gpedia/ Торгівля_людьми

[4] UNODC launches Global Initiative to Fight Human Trafficking. Available: http://www .unodc.org/unodc/en/press/releases/2007-03-26.html 
[5] World economic situation and prospects 2013 (2013). 1st Ed. New York: United Nations

[6] Економіка України за 2015 рік. У ряд. кур. № 24 (2016)

[7] Еконаоміка України за 2016 рік. Уряд. кур. № 28 (2017)

[8] Економіка України за 2017 рік. У ряд. кур. № 30 (2018)

[9] Васильківський Д. М., Осійчук О. А. Зовнішня трудова міграиія в Украйні: сучасний стан, причини, наслідки. Вісн. Хмел. нац. ун. № 1. С. 97101 (2009)

[10] Населення Украӥни. Трудова еміграція в Украӥні. Кїыв: Ин-т демографіы та соціальних досліджень ім. М.В. Птухи НАН України (2010)

[11] Јдиний звіт про кримінальні правопорушення за січень-грудень 2014 року. Available: http://www.gp.gov.ua/ua/stst2011.html (2015)

[12] Єдиний звіт про кримінальні правопорушення за січень-грудень 2015 pоку. Available: http://www.gp.gov.ua/ua/stst2011.html (2016)

[13] Єдиний звіт про кримінальні правопорушення за січень-грудень 2016 pоку. Available: http://www.gp.gov.ua/ua/stst2011.html (2017)

[14] Сдиний звіт про кримінальні правопорушення за січень-грудень 2017 року. Available: http://www.gp.gov.ua/ua/stst2011.html (2018)

[15] Бабенко А. М., Орещенко А. В. Можливості картографічних методів дослідження у інформаційно-аналітичному забезпеченні протидіь торгівлі людьми. Актуальні питання боротьби з торгівлею людьми в умовах проведення антитерористичної операції (збройного конфлікту): зб. матеріалів міжнар. круглого столу. Киыв: ВД. «Дакор». С. 42-48 (2017)

[16] Чисельність наявного населення України на 1 січня 2017 року. Київ: Держ. служба статистики України (2017)

[17] Яницкий О. Н. Социальные реальности и сочиальные мирами. Соч. риска: ключ. идеи. Мир Росс. Т. 12. № 1. С. 3-35 (2003)

[18] Мозговая А. В. Сочиология риска: возможности синтеза теории и әмпирическиого знания. Риск в социальном пространстве / под ред. А. В. Мозговой. Москва: Ин-т социологии РАН (2001)

[19] Мазаник М. Н. Мифологема «риска» в сочиальных науках и массовом сознании. Философия и ценности современной культуры: материалы Междунар. научн. конф. (Минск, 10-11 октября 2013 г.). Минск: БГУ. С. 582-584 (2014)

[20] Клямкин И.М., Тимофеев Л.М. Теневая Россия: Экономикосоииологическое исследование. Москва: Рос. гос. гуманит. ун-т (2000)

[21] Sagan S. D. The Limits of Safety. Organizations, Accidents, and Nuclear Weapons. Princeton: Princeton Univ. Press (1995)

[22] Beck U. Risk Society. Toward a New Modernity. London: SAGE (1992)

[23] Douglas M. Risk Acceptability According to the Social Sciences. New York: Russel Sage Foundation (1985)

[24] Douglas M. Risk and Blame: Essays in Cultural Theory. London: Routledge (1992)

[25] Douglas M. Risk Acceptability According to the Social Sciences. New York: Russel Sage Foundation (1985)

[26] Rosa E.A. Metatheoretical Foundations for Post-Normal Risk, JRR 1(1), 15-44 (1998)

[27] Населення України. Трудова еміграція в Украыні. Київ: Ин-т демографії та соціальних досліджень ім. М.В. Птухи НАН України (2010) 
[28] Батиргарејва В. С. Аналітична довідка за результатами узагальнення кримінальних справ за ст.149 КК України 2001 року (ст. $124^{1}$ КК Украыни 1960 року), розглянутих судами України за 1998-2004 рр. Харків: Архів Институту вивчення проблем злочинності АПрН України (2005)

[29] Васильјва М. О., Касько В. В., Орлеан А. М., Пустова О. В. Україна як країна призначення для торгівлі людьми: матеріали для практичного використання працівниками прикордонноы служби, правоохоронних органів та суддями. Киыв: Фенікс (2012)

[30] Батиргарејва В. С. Торгівля людьми в Україні: реальність та омана. Актуальні питання боротьби з торгівлею людьми в умовах проведення антитерористичної операції (збройного конфлікту): зб. матеріалів міжнар. круглого столу. Київ: ВД. «Дакор». С. 31-37 (2017) 